\title{
STUDI POTENSI PENYEMAIAN DAN PEMBIBITAN TANAMAN MENGKUDU PADA BEBERAPA KOMPOSISI MEDIA TANAM
}

\author{
(Study on Seeding Potency and Seedling of Morinda on the Plant Media Composition) \\ DJOKO EKO HADI SUSILO, MOHAMMAD HERTOS, DAN FAHRUDDIN ARFIANTO
}

Dosen Program Studi Agroteknologi Fakultas Pertanian dan Kehutanan

Universitas Muhammadiyah Palangkaraya

e-mail : masdjoko_ns@yahoo.co.id

\begin{abstract}
The purpose of this research is to know and find the growth potency on the seeds germination and seedling growth of Morinda plant from seed on the kind of plant media composition from March to June 2014 in Panarung, Palangka Raya.

This experiment used single treatment with randomized complete design, each treatment was repeated ten times. The treatment consist of single factor is kind of plant media composition in five mixture compotition and ratio : $s_{1}=$ mixture of mineral soil + peat soil + ash + organic fertilizer (1:1:1:1), $s_{2}=$ mixture of mineral soil + ash + organic fertilizer (1:0,5:0,5), $s_{3}=$ mixture of peat soil + ash + organic fertilizer (1:0,5:0,5), $s_{4}=$ mixture of mineral soil + ash + organic fertilizer (1:1:1), and $s_{5}=$ mixture of peat soil + ash + organic fertilizer (1:1:1). Variable respons of this research is time of germination, percentage of seeding, hingh of plant, number of leaf, diameter of stem, and leaf area on 12 weeks after seeding.

The experiment resulted, showed that plant media composition is very significant to high plant and leaf area seeding of morinda, but not significant to number of leaf and diameter of stem on 12 weeks after seeding. Plant media composition that mixture of peat soil + ash + organic fertilizer (1:1:1) is the best treatment to support germination and increase seedling growth.
\end{abstract}

Keywords: seeding, seedling, morinda, plant media compotition

\section{ABSTRAK}

Penelitian ini bertujuan untuk mengetahui dan mendapatkan potensi tumbuh pada penyemaian biji (benih) dan pertumbuhan bibit tanaman mengkudu asal biji pada beberapa komposisi media tanam. Penelitian ini dilaksanakan pada bulan Maret-Juni 2014 di Kelurahan Panarung, Kota Palangka Raya.

Perlakuan satu faktor menggunakan Rancangan Acak Lengkap dengan 10 (sepuluh) kali pengulangan berupa komposisi media tanam (S) yang terdiri dari 5 komposisi, yaitu : $s_{1}=$ campuran tanah mineral + tanah gambut + abu + pupuk kandang (1:1:1:1), $\mathrm{s}_{2}=$ campuran tanah mineral + abu + pupuk kandang (1:0,5:0,5), $\mathbf{s}_{3}=$ campuran tanah gambut + abu + pupuk kandang $(1: 0,5: 0,5), s_{4}=$ campuran tanah mineral + abu + pupuk kandang (1:1:1), dan $\mathrm{s}_{5}=$ campuran tanah gambut + abu + pupuk kandang (1:1:1). Pengamatan dilakukan terhadap waktu tumbuhnya semai atau berkecambah (hari setelah semai), persentase tumbuhnya benih (\%), tinggi tanaman $(\mathrm{cm})$, jumlah daun (daun), diameter batang $(\mathrm{cm})$, dan luas daun $\left(\mathrm{cm}^{2}\right)$ bibit tanaman mengkudu umur 12 minggu setelah semai.

Hasil penelitian ini menunjukkan bahwa komposisi media tanam berpengaruh sangat nyata terhadap pertumbuhan tinggi bibit dan luas daun bibit mengkudu, tetapi tidak berpengaruh terhadap jumlah daun dan diameter batang bibit mengkudu umur 12 minggu setetalah semai. Komposisi media tanam berbentuk campuran tanah gambut+abu+pupuk kandang (dengan perbandingan 1:1:1) mendukung perkecambahan dan memberikan pertumbuhan bibit yang terbaik.

Kata kunci : penyemaian, pembibitan, mengkudu, komposisi media tanam 


\section{PENDAHULUAN}

Mengkudu (Morinda citrifolia L.), adalah tanaman hortikultura dan cukup potensial untuk dikebunkan. Tanaman mengkudu sering disebut noni. Karena mempunyai banyak manfaat dan digunakan mengobati banyak penyakit. Masyarakat Indonesia memanfaatkan tanaman mengkudu hampir pada seluruh bagian tubuh tanaman. Seringnya digunakan sebagai bahan pangan (jus, rujak, sirup) dari buahnya, juga sebagai bahan pangan dan obat-obatan dari daunnya. Kulit akar dan batangnya digunakan sebagai bahan pewarna tekstil (Tadjoedin dan Iswanto, 2002).

Penyebaran tanaman mengkudu maupun pemanfaatannya di masyarakat sudah dilakukan hampir di seluruh nusantara, namun kelestarian pemanfaatan komoditas mengkudu ini belum ada jaminan akibat populasinya di lahan masyarakat tumbuh secara liar dan relatif sedikit dibudidayakan. Hal ini mendorong masyarakat untuk membudidayakan dengan menyediakan bibit tanaman muda yang dapat dilakukan secara pengadaan bibit melalui penyemaian biji dan pembibitan (Tadjoedin dan Iswanto, 2002). Sedangkan upaya penyemaian dan pembibitan diperlukan tata cara yang tepat sehingga keberhasilan dan kualitas dari bibit tanaman mengkudu yang dihasilkan menjadi lebih baik.

Keberadaan tanaman mengkudu di Provinsi Kalimantan Tengah masih belum banyak dibudidayakan oleh masyarakat dan ada dalam bentuk tumbuh secara liar. Pada tahun 2008, di wilayah provinsi Kalimantan Tengah baru terdapat 42.655 pohon dengan produktivitas $2,78 \mathrm{Kg}$ buah/pohon. Sedangkan di Kota Palangka Raya hanya sekitar 100 pohon yang ada dengan produktivitas hanya $1,75 \mathrm{Kg}$ buah/pohon (Anonim, 2009). Hal ini menurut informasi masyarakat karena kebutuhannya masih terbatas sebagai tanaman pekarangan dan jarang digunakan secara rutin, bahkan belum digunakan sebagai tanaman yang komersial.

Kalimantan Tengah sebagai lokasi yang potensial sebagai pengembangan kawasan budidaya sebesar $71 \%$ dari total luas wilayah atau sebesar 10.776.860 Ha untuk dicapai sebagai peluang pengembangan komoditas tanaman pertanian (Bhermana et al., 2009), termasuk bisa digunakan untuk budidaya tanaman mengkudu.

Membudidayakan tanaman dilakukan dengan memperhatikan seluruh aspek kultur teknis yang mencakup semua faktor-faktor pertumbuhan tanaman yang bersifat internal dan eksternal. Memperhatikan setiap aspek dalam budidaya merupakan tindakan bijaksana karena merupakan faktor-faktor yang mempengaruhi pertumbuhan tanaman dan menyangkut keberhasilan di akhir budidaya. Masalah pertanian yang umumnya berupa terbatasnya pertumbuhan dan produksi yang rendah dikarenakan secara teknis budidaya kurang memperhatikan dan menyiapkan faktor pertumbuhan secara maksimal bagi tanaman, sedangkan interaksi secara baik dari berbagai faktor pertumbuhan sangat dibutuhkan untuk menentukan pertumbuhan dan hasil tanaman (Mardjuki, 1994).

Membudidayakan tanaman umumnya dilakukan dengan pengadaan tanaman muda (bibit) yang dapat dimulai dengan menyemai biji (secara generatif) maupun menggunakan bagian tanaman induknya (secara vegetatif). Sebelum bibit ditanam di lapangan (lahan budidaya) maka dipelihara terlebih dulu pada sistem pembibitan. 
Hal ini memerlukan pertimbangan dan ketepatan tindakan untuk menyediakan dan mengelola media tanam karena cukup menentukan keberhasilan pertumbuhan, pemeliharaan, dan produksi tanaman.

Teknis budidaya tanaman yang harus diperhatikan salah satunya berupa pengelolaan media tanam, berupa komposisi perbandingan bahan-bahan penyusun media tanam yang secara langsung dan tidak langsung akan meningkatkan kuantitas dan kualitas hasil tanaman yang dibudidayakan. Tanah dan campurannya (media tanam) dalam budidaya tanaman tidak hanya sebagai tempat menanam, berdirinya tanaman, rumah perakaran dan sebagainya, namun lebih dari itu merupakan sumber nutrisi yang semestinya cukup dan berkelanjutan bagi tanaman. Oleh karena itu pengelolaan media tanam dan penyediaan media tanam dengan baik akan menghindari kelemahan-kelemahan budidaya dan resiko serta kerugian dapat ditekan (AAK, 1995).

Berawal dari berbagai macam faktor yang mempengaruhi pertumbuhan tanaman tersebut, maka salah satu tindakan berupa pengelolaan tanah (media tanam) yang meliputi teknik penyediaan media tanam dengan baik diharapkan dapat mendukung pertumbuhan dan hasil yang baik pula bagi tanaman budidaya. Begitu juga dengan media tanam yang baik, akan memudahkan dalam pemeliharaan tanaman budidaya untuk segala jenis tanaman menggunakan pot maupun di lahan.

Sehubungan dengan pengelolaan media tanam, penyediaan tanaman muda untuk budidaya tanaman mengkudu juga perlu dilakukan teknis penyemaian dan pembibitannya.
Tadjoedin dan Iswanto (2002) menjelaskan bahwa media semai dan media pembibitan yang baik dianjurkan berupa media yang subur, mengandung cukup humus, drainasenya baik, dan kelembapannya sesuai. Media dapat berupa campuran tanah liat halus, pasir, kompos atau pupuk kandang. Sedangkan media di pembibitan sangat menentukan kualitas bibit yang akan dilakukan perawatan. Dikarenakan bibit tanaman mengkudu merupakan tanaman muda yang masih rentan terkena stress akibat mengalami perubahan lingkungan, maka media tanam yang baik akan membantu memberikan lingkungan yang baik pula berupa perubahan perbaikan suhu, kelembapan, dan tidak mudah mengalami kekeringan yang tiba-tiba.

Untuk mendukung cepatnya maupun keberhasilan penyemaian biji (benih) mengkudu dan memenuhi penyediaan unsur hara serta mempercepat pertumbuhan bibit mengkudu di pembibitan maka beberapa komposisi media diharapkan dapat mengkaji kebutuhan dan sebagai media tanam yang efektif bagi semaian dan bibit tanaman mengkudu yang berkualitas.

Penelitian ini bertujuan untuk mengetahui dan mendapatkan potensi tumbuh pada penyemaian biji (benih) dan kemampuan pertumbuhan bibit tanaman mengkudu asal biji pada beberapa komposisi media tanam. Sedangkan hasil penelitian ini diharapkan dapat memberikan kontribusi untuk masyarakat, petani, dan petugas penyuluh pertanian sebagai informasi dan pengembangan ilmu pengetahuan bidang pertanian untuk teknis penyemaian dan pembibitan budidaya tanaman mengkudu yang paling mendukung pada beberapa komposisi media tanam. 


\section{METODOLOGI}

Penelitian ini dilaksanakan selama 4 (empat) bulan, pada bulan Maret - Juni 2014 di daerah Kelurahan Panarung RT.003/RW.014, Kecamatan Pahandut, Kota Palangka Raya, Provinsi Kalimantan Tengah. Bahan yang digunakan adalah biji tanaman mengkudu, tanah mineral, tanah gambut, abu bakaran vegetasi, pupuk kandang kotoran ayam, kapur dolomit, dan air. Peralatan yang digunakan berupa cetok, kotak semai, polybag ukuran kecil $(10 \times 15 \mathrm{~cm})$, gayung penyiram, pisau cuter, thermometer, handsprayer, kamera, kertas milimeter blok, penggaris, kalkulator, jangka sorong (digital caliper), laptop komputer, dan alat tulis.

Rancangan perlakuan berupa percobaan faktor tunggal menggunakan Rancangan Acak Lengkap (RAL) dengan 10 (sepuluh) kali pengulangan (Mattjik dan Sumertajaya, 2002). Perlakuan percobaan berupa komposisi media tanam (S) yang terdiri dari 5 komposisi, yaitu : $\mathrm{s}_{1}=$ campuran tanah mineral + tanah gambut + abu + pupuk kandang (1:1:1:1), $\mathrm{s}_{2}=$ campuran tanah mineral + abu + pupuk kandang $(1: 0,5: 0,5)$, $\mathrm{s}_{3}=$ campuran tanah gambut $+\mathrm{abu}+$ pupuk kandang $(1: 0,5: 0,5), s_{4}=$ campuran tanah mineral + abu + pupuk kandang (1:1:1), dan $\mathrm{S}_{5}=$ campuran tanah gambut + abu + pupuk kandang (1:1:1).

Pengamatan dilakukan terhadap waktu tumbuhnya semai atau berkecambah (hari setelah semai), persentase tumbuhnya benih (\%), tinggi tanaman $(\mathrm{cm})$, jumlah daun (daun), diameter batang $(\mathrm{cm})$, dan luas daun $\left(\mathrm{cm}^{2}\right)$ bibit tanaman mengkudu umur 12 minggu setelah semai. Analisis pengukuran luas daun menggunakan metode panjang kali lebar (Sitompul dan Guritno,
1995) menggunakan nilai $k=0,67328$ (Susilo, 2013). Data hasil pengamatan dianalisis menggunakan analisis ragam ( $\mathrm{Uji} F$ ) pada taraf $\alpha=0,05$ dan 0,01 . Uji lanjut beda rataan menggunakan uji Beda Nyata Jujur taraf 0,05 (Mattjik dan Sumertajaya, 2002).

\section{HASIL DAN PEMBAHASAN}

\section{Hasil Pengamatan \\ Perkecambahan}

Hasil pengamatan kecambah biji mengkudu berupa umur benih mulai tumbuh (berkecambah) dan persentase benih tumbuh (kecambah) pada saat penyemaian yang menggunakan masingmasing komposisi media tanam disajikan pada Tabel 1 dan digambarkan pada Gambar 1 dan 2.

\section{Pertumbuhan Bibit}

Hasil analisis ragam menunjukkan bahwa perlakuan beberapa komposisi media memberikan pengaruh yang sangat nyata terhadap pertumbuhan tinggi dan luas daun bibit mengkudu, namun tidak berpengaruh terhadap jumlah daun dan diameter batang bibit mengkudu umur 12 minggu setetalah semai dari biji. Hasil uji rataan tinggi bibit dan luas daun bibit mengkudu setelah disemai sampai umur 12 minggu setelah semai disajikan pada Tabel 2 dan digambarkan pada Gambar 3 dan 4.

Berdasarkan hasil pengamatan perkecambahan (Tabel 1) dan hasil uji rataan pertumbuhan bibit mengkudu pada umur 12 minggu setelah semai (Tabel 2) menunjukkan bahwa perlakuan $\mathrm{s}_{5}$ yaitu berupa komposisi media penyemaian dan pembibitan dengan bentuk campuran tanah gambut+abu+pupuk kandang (dengan perbandingan 1:1:1) nampak mendukung 
Tabel 1. Umur benih mulai berkecambah dan persentase kecambah benih mengkudu setelah disemai pada beberapa komposisi media tanam

\begin{tabular}{ccc}
\hline Perlakuan & $\begin{array}{c}\text { Umur mulai berkecambah } \\
\text { (hari setelah semai) }\end{array}$ & $\begin{array}{c}\left.\text { Persentase kecambah }{ }^{\star}\right) \\
(\%)\end{array}$ \\
\hline $\mathrm{s}_{1}$ & 38 & 90 \\
$\mathrm{~s}_{2}$ & 41 & 85 \\
$\mathrm{~s}_{3}$ & 38 & 95 \\
$\mathrm{~s}_{4}$ & 38 & 95 \\
$\mathrm{~s}_{5}$ & 37 & 100 \\
\hline
\end{tabular}

Keterangan : *) dari penyemaian 40 benih mengkudu pada masing-masing perlakuan

Tabel 2. Hasil uji lanjut rataan tinggi bibit dan luas daun bibit mengkudu umur 12 minggu setelah semai pengaruh beberapa komposisi media tanam

\begin{tabular}{ccccc}
\hline Perlakuan & $\begin{array}{c}\text { Tinggi bibit } \\
(\mathrm{cm})\end{array}$ & $\begin{array}{c}\text { Jumlah daun bibit } \\
(\text { daun })\end{array}$ & $\begin{array}{c}\text { Diameter batang bibit } \\
(\mathrm{cm})\end{array}$ & $\begin{array}{c}\text { Luas daun bibit } \\
\left(\mathrm{cm}^{2}\right)\end{array}$ \\
\hline $\mathrm{s}_{1}$ & $17,60^{\text {ab }}$ & 11,20 & 0,59 & $546,60^{\mathbf{a}}$ \\
$\mathrm{s}_{2}$ & $17,05^{\text {a }}$ & 10,80 & 0,58 & $518,39^{\text {a }}$ \\
$\mathrm{s}_{3}$ & $18,60^{\mathbf{b}}$ & 11,40 & 0,60 & $549,55^{\text {a }}$ \\
$\mathrm{s}_{4}$ & $18,85^{\mathbf{b}}$ & 11,00 & 0,61 & $550,62^{\text {a }}$ \\
$\mathrm{s}_{5}$ & $20,30^{\mathrm{c}}$ & 12,40 & 0,60 & $628,41^{\mathbf{b}}$ \\
\hline
\end{tabular}

$\begin{array}{rrrrr}\text { BNJ 5\% } & 1,43 & - & - & 75,18\end{array}$

Keterangan : nilai rataan yang didampingi huruf yang sama pada kolom yang sama tidak berbeda nyata menurut uji BNJ 5\%

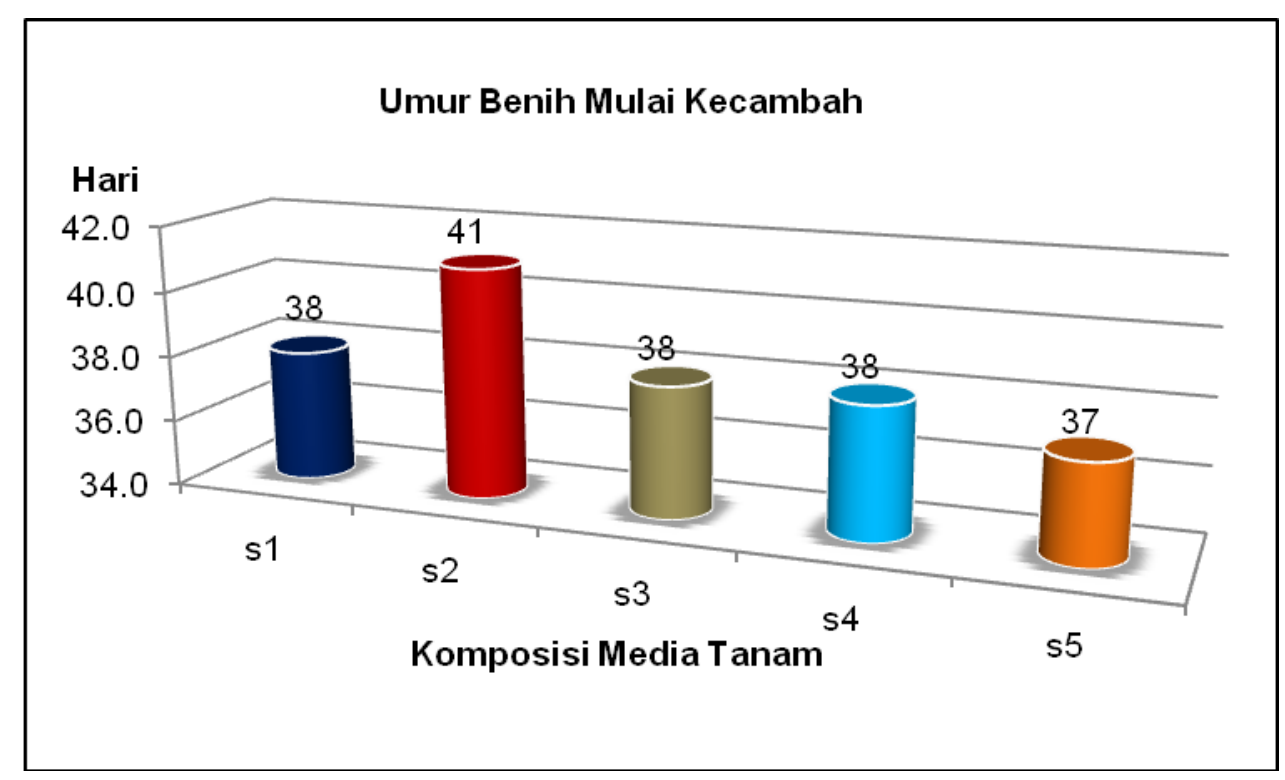

Gambar 1. Umur benih mengkudu mulai berkecambah setelah disemai pada beberapa komposisi media tanam 


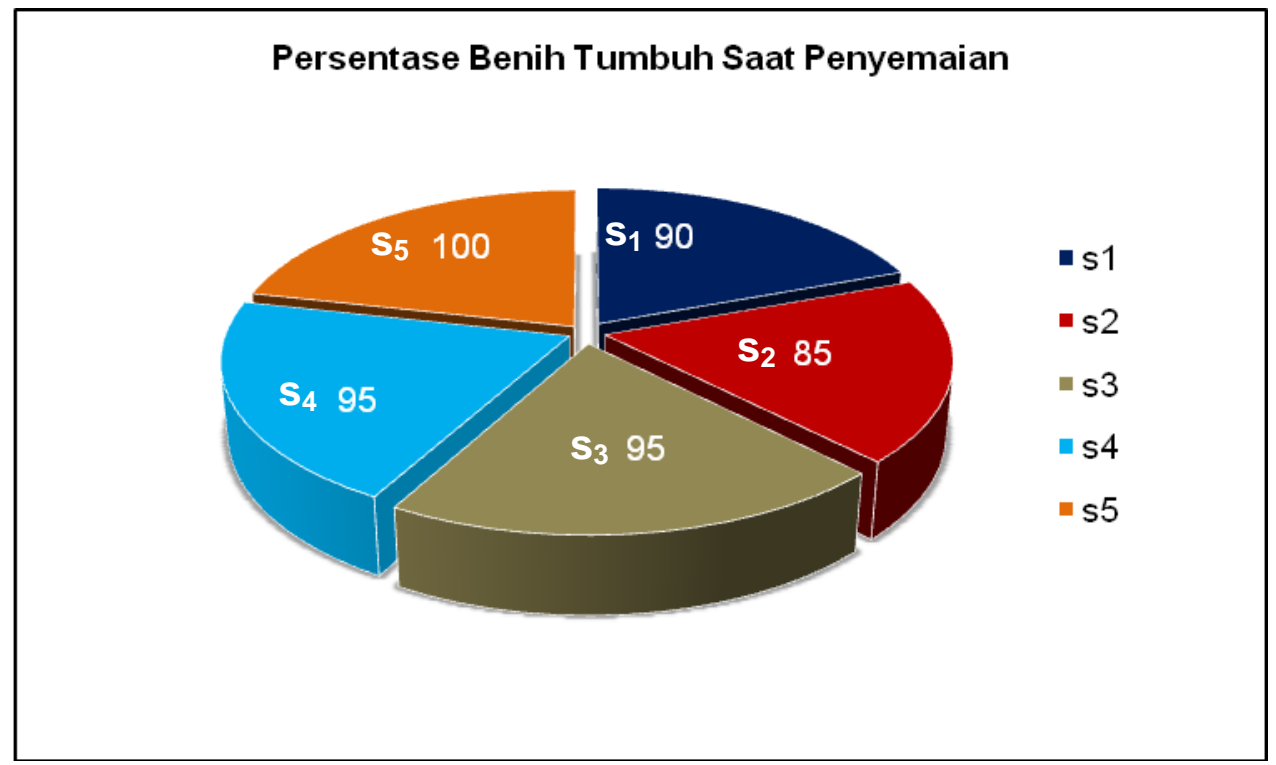

Gambar 2. Persentase benih mengkudu berkecambah setelah disemai pada beberapa komposisi media tanam

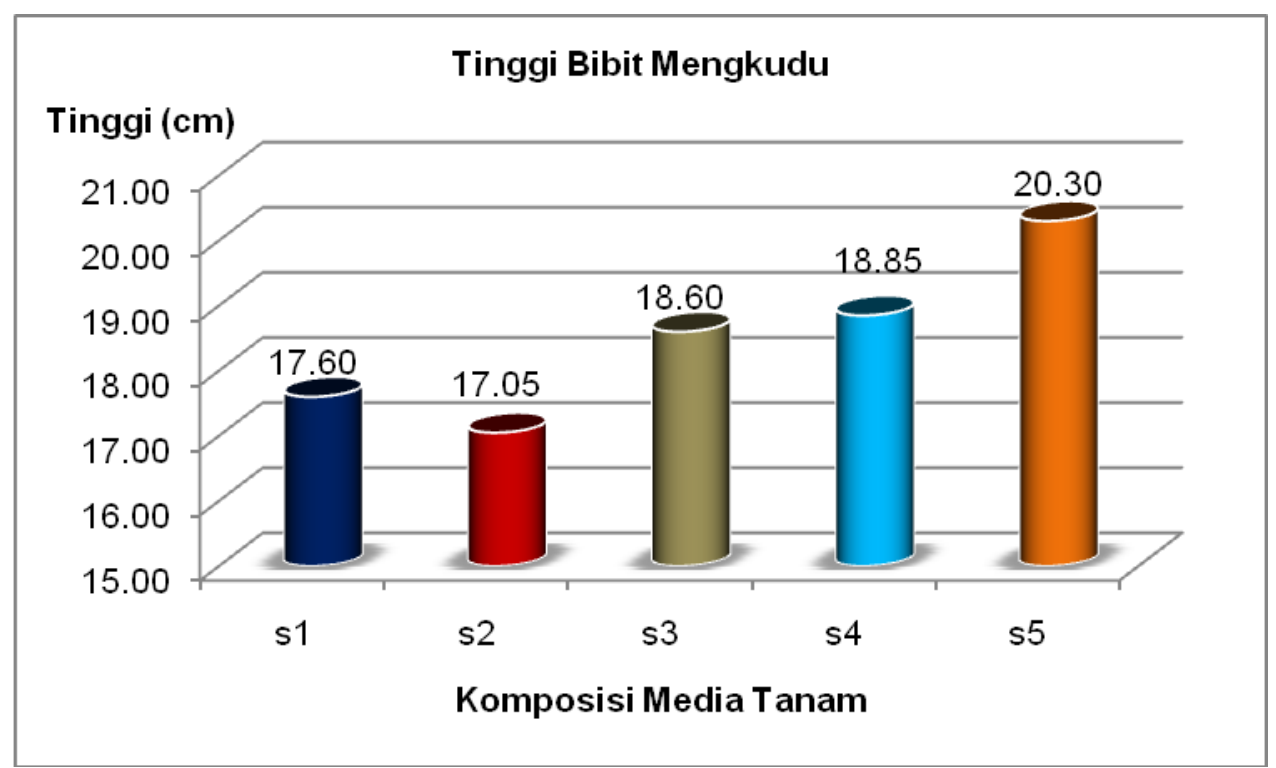

Gambar 3. Pertumbuhan tinggi bibit mengkudu pada umur 12 minggu setelah disemai pada beberapa komposisi media tanam

perkecambahan dan memberikan pertumbuhan bibit yang terbaik sehingga berbeda nyata dengan perlakuan lainnya (perlakuan $s_{1}, s_{2}, s_{3}$ dan $s_{4}$ ) meskipun perlakuan lainnya tersebut juga memiliki tingkat keberhasilan yang relatif tinggi dalam hal berkecambah dan pertumbuhan bibit mengkudu. 


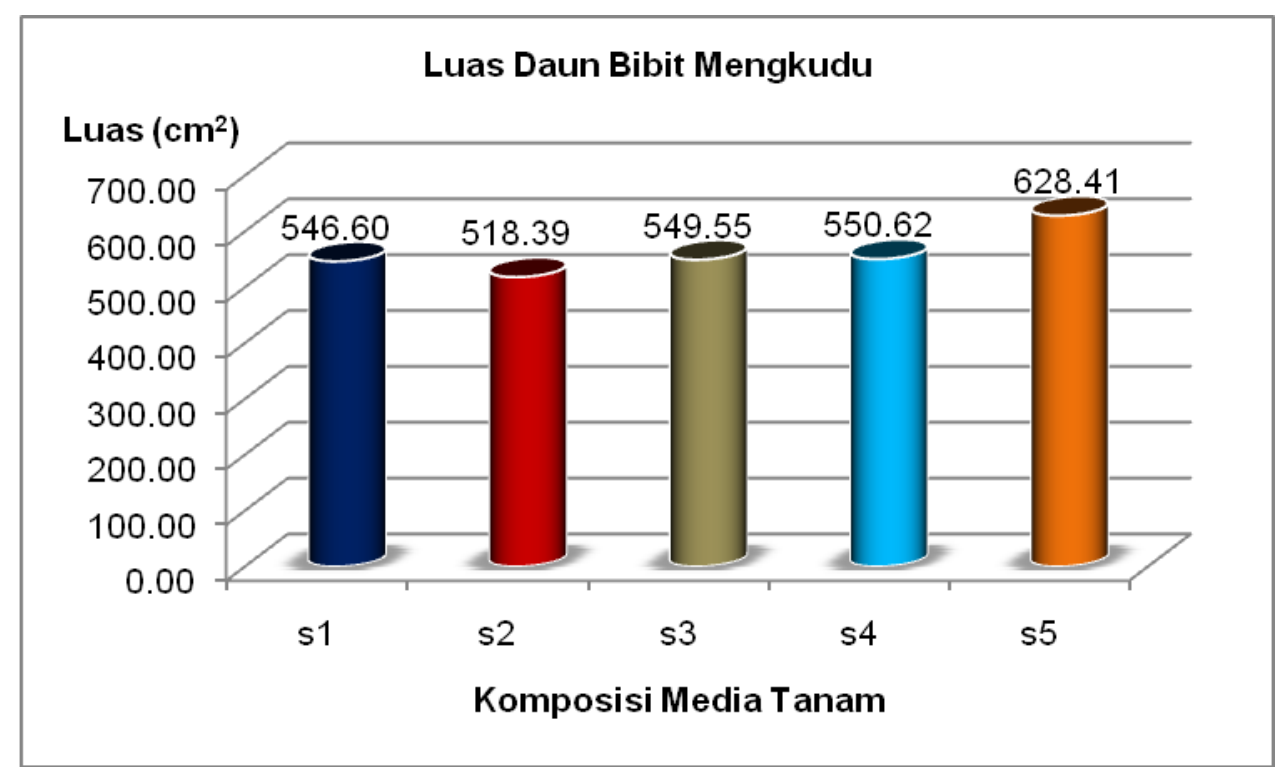

Gambar 4. Pertumbuhan luas daun bibit mengkudu pada umur 12 minggu setelah disemai pada beberapa komposisi media tanam

\section{Pembahasan}

\section{Perkecambahan}

Berdasarkan Tabel 1, bahwa rata-rata penyemaian mengalami keberhasilan kecambah yang baik. Hal ini dibuktikan dengan rata-rata waktu berkecambah pada seluruh perlakuan masih dalam taraf yang tepat waktu dalam berkecambah, yaitu berkecambah dalam waktu antara 37-41 hari setelah semai. Penggunaan perlakuan $\mathrm{s}_{5}$ berupa campuran tanah gambut+abu+pupuk kandang (perbandingan 1:1:1) menyebabkan perkecambahan lebih cepat tumbuh yaitu pada umur 37 hari setelah semai dan paling cepat dibandingkan perlakuan komposisi media lainnya yang memiliki waktu berkecambah yang lebih lambat.

Kondisi penggunaan beberapa komposisi media penyemaian ini, nampaknya memberikan alternatif yang digolongkan masih dalam taraf umur berkecambah yang masih layak karena masih memberikan kondisi saat berkecambah yang secara umum sesuai dengan masa berkecambah biji tanaman mengkudu. Benih mengkudu apabila disemai bisa tumbuh berkecambah pada umur 21-24 hari setelah semai (Lendri, 2003), atau umur 27 - 34 hari setelah semai (Pujiastuti et. al, 2004), dan bahkan bisa pada umur 1 bulan setelah semai (Litbang Deptan, 2013). Begitu juga persentase perkecambahan biji mengkudu yang cukup tinggi dan mencapai $100 \%$ tersebut menunjukkan bahwa komposisi media memberikan kondisi yang baik dalam mendukung proses perkecambahan.

\section{Pertumbuhan Bibit}

Berdasarkan hasil analisis ragam dan hasil uji rataan (Tabel 2), bahwa jumlah daun dan diameter batang bibit mengkudu tidak berpengaruh nyata. Hal ini menunjukkan bahwa 
pertumbuhan bibit mengkudu pada semua komposisi media tanam yang digunakan adalah memiliki pertumbuhan yang seragam dalam hal pertumbuhan jumlah daun dan diameter batangnya. Kondisi ini selaras dengan masa pertumbuhan bibit pada saat pertumbuhan awal memiliki pertumbuhan yang relatif sama pada jumlah daun dan diameter batang. Litbang Deptan (2013) menjelaskan bahwa biasanya pertumbuhan jumlah daun dan diameter batang bibit mengkudu masih seragam, dan diameter batang baru berkembang setelah umur 3-4 bulan setelah semai karena batangnya mulai berkayu dengan diameter $0,8-1,0 \mathrm{~cm}$, meskipun pada penelitian ini pertumbuhannya masih mampu mencapai diameter batang hanya sebesar 0,58-0,61 cm.

Berpengaruhnya perlakuan komposisi media tanam terhadap tinggi tanaman dan luas daun bibit tanaman mengkudu di persemaian dan pembibitan ini menunjukkan bahwa bahan-bahan yang menyusun komposisi media yang digunakan memberikan peran yang berbeda dalam mendukung tumbuhnya kecambah dan bibit tanaman mengkudu selama pembibitan. Pujiastuti et. al (2004) menjelaskan bahwa komposisi media memberikan pengaruh sangat nyata terhadap persentase perkecambahan, tinggi plumula, dan umur berkecambah benih mengkudu. Hal ini dikarenakan dengan adanya komposisi media tanam tersebut berhubungan dengan proses pengontrolan volume air siraman dan kandungan air media yang mampu dipertahankan dan menyangkut kondisi kelarutan unsur hara sehingga tersedia bagi perakaran. Begitu juga komposisi media juga menentukan terhindarnya kondisi keringnya media secara cepat.
Tabel 2 juga menunjukkan bahwa penggunaan komposisi media penyemaian dan pembibitan dengan bentuk campuran tanah gambut+abu+pupuk kandang (perbandingan 1:1:1) nampaknya mendukung perkecambahan dan memberikan pertumbuhan bibit yang terbaik sehingga berbeda nyata dengan perlakuan lainnya (perlakuan $\mathrm{s}_{1}, \mathrm{~s}_{2}, \mathrm{~s}_{3}$ dan $\mathrm{s}_{4}$ ). Media campuran tanah gambut+abu+pupuk kandang (perbandingan 1:1:1) tersebut nampaknya memberikan kondisi dan peran yang terbaik bagi proses perkecambahan dan pertumbuhan bibit mengkudu sampai umur 12 minggu setelah semai. Membaiknya tanah gambut akibat peran abu dan pupuk kandang yang dicampurkan menjadikan media lebih gembur dan subur yang mampu mendorong proses perkecambahan dan menyediakan unsur hara secara cukup sehingga selama berkecambah dan tumbuh sebagai bibit lebih bertahan dan terpenuhi faktor tumbuhnya. Peran ganda dari tanah gambut, abu dan pupuk kandang selain sebagai media juga sekaligus ternyata menjaga struktur dan kesuburan media. Hal ini yang mengakibatkan campuran komposisi ini lebih menghasilkan pertumbuhan bibit yang lebih baik dibandingkan dengan perlakuan campuran komposisi media yang lain. Lendri (2003) menjelaskan bahwa bahan media yang dicampurkan selain tanah mineral, diharapkan mempunyai peran ganda sebagai bahan penjaga struktur dan sekaligus menyuburkan tanah meskipun pada penyemaian dan pembibitan secara umum juga bisa menggunakan bahan lain yaitu pasir dan kompos.

Pada perlakuan komposisi media lainnya (Tabel 2) menghasilkan pertumbuhan bibit yang lebih rendah dari segi tinggi bibit maupun luas 
daunnya dikarenakan sejak perkecambahan maupun saat pertumbuhan bibit, kondisi komposisi media sudah kurang mendukung dan menguntungkan lagi bagi pertumbuhan bibit. Hal ini dapat dianalisa dari segi bahan-bahan yang dicampurkan tersebut perannya kemungkinan menjadi terbatas dan sebagai pembatas.

Bahan media yang berupa tanah mineral yang dicampurkan sepertinya menjadi faktor pembatas pada perkecambahan dan pembibitan dalam komposisi media ini, sehingga kondisi campuran media menjadi kurang menguntungkan bagi benih dan bibit untuk tumbuh dan berkembang. Diperkirakan komposisi media yang mengandung campuran tanah mineral menjadi lebih padat seiring waktu saat pemeliharaan dan pertumbuhan bibit sehingga kurang menguntungkan bagi perakaran bibit. Selain itu, perbandingan komposisi juga menjadi kurangnya jaminan jumlah penyediaan unsur hara bagi bibit selama pertumbuhannya. Lendri (2003) menjelaskan juga bahwa pada media persemaian yang mengandung tanah mineral, maka lamakelamaan menjadi lebih padat dan tidak gembur lagi sehingga bisa menghambat pertumbuhan bibit tanaman mengkudu.

\section{KESIMPULAN DAN SARAN}

\section{Kesimpulan}

Penelitian ini menghasilkan beberapa kesimpulan sebagai berikut :

a. Perlakuan komposisi media penyemaian dan pembibitan berpengaruh sangat nyata terhadap pertumbuhan tinggi bibit dan luas daun bibit mengkudu pada umur 12 minggu setelah semai, tetapi tidak berpengaruh terhadap jumlah daun dan diameter batang bibit mengkudu pada umur 12 minggu setetalah semai.

b. Perlakuan komposisi media penyemaian dan pembibitan dengan bentuk campuran tanah gambut+abu+pupuk kandang (perbandingan 1:1:1) memberikan pertumbuhan bibit yang terbaik.

c. Kemampuan tumbuh terbaik akibat komposisi media penyemaian dan pembibitan berupa campuran tanah gambut+abu+pupuk kandang (perbandingan 1:1:1) yaitu mendukung berkecambah umur 37 hari setelah semai, persentase tumbuh sebesar $100 \%$, pertumbuhan bibit umur 12 minggu setelah semai berupa tinggi bibit mencapai $20,30 \mathrm{~cm}$, jumlah daun sebanyak 12,40 daun, diameter batang sebesar $0,60 \mathrm{~cm}$, dan luas daunnya mencapai $628,41 \mathrm{~cm}^{2}$.

\section{Saran}

Penelitian ini menghasilkan beberapa saran sebagai berikut :

a. Apabila menyemai dan membibit tanaman mengkudu yang berasal dari biji maka sebaiknya menggunakan komposisi media dengan bentuk campuran tanah gambut+abu+pupuk kandang (perbandingan 1:1:1) untuk mendukung perkecambahan dan pertumbuhan bibit dengan baik.

b. Selain memperhatikan komposisi media, maka perlu dilakukan penelitian pertumbuhan bibit berupa pemupukan bibit tanaman mengkudu. 


\section{UCAPAN TERIMA KASIH}

Ucapan terima kasih disampaikan kepada Universitas Muhammadiyah Palangkaraya yang telah memfasilitasi dan mendanai pembiayaan penelitian ini pada Tahun Anggaran 2014.

\section{DAFTAR PUSTAKA}

AAK, 1995. Petunjuk Praktis Bertanaman Sayuran. Kanisius. Yogyakarta.

Anonim, 2009. Statistik Pertanian Tanaman Pangan dan Hortikultura Kalimantan Tengah Tahun 2008. Dinas Pertanian dan Peternakan Provinsi Kalimantan Tengah. Palangka Raya.

Bhermana A., R. Massinai, L. Rangin, dan M. Siahaan, 2009. Potensi Pengembangan Wilayah untuk Pertanian, Perkebunan, Hortikultura, dan Peternakan di Kalimantan Tengah. Balai Pengkajian Teknologi Pertanian Kalimantan Tengah. Palangka Raya.

Lendri, S., 2003. Teknik Pembibitan Mengkudu Pada Berbagai Media. Buletin Teknik Pertanian. Vol 8, Nomor 1, 2003. Hal 5-7.

Litbang Deptan, 2013. Optimalkan Produktivitas Mengkudu.

http://pustaka.litbang.deptan.go.id/publikasi/ bt081032.pdf. Diakses pada tanggal 5 Desember 2013.

Mardjuki, A., 199. Pertanian dan Masalahnya. Andi Offset. Yogyakarta.

Mattjik, A. A. dan I.M. Sumertajaya. 2002. Perancangan Percobaan dengan Aplikasi SAS dan Minitab. Jilid I Edisi Ke-dua. IPB PRESS. Bogor.

Pujiastuti, E.S., B.L. Siregar, dan D. Sitinjak. 2004. Pengaruh Komposisi Media Tanam dan Volume Air Siraman terhadap Perkecambahan Benih Mengkudu (Morinda citrifolia L,). Majalah IImiah Media Unika ISSN 0852-1832. Tahun 16, Nomor 46 (Januari-Februari) 2004. Hal 448-458.
Sitompul, S.M., dan B. Guritno, $1995 . \quad$ Analisis Pertumbuhan Tanaman. Gadjah Mada University Press. Yogyakarta.

Susilo, D. E. H., 2013. Perilaku Pertumbuhan Daun Bibit Tanaman Mengkudu (Morinda citrifolia L.) di Tanah Gambut Pedalaman. Fakultas Pertanian dan Kehutanan. Universitas Muhammadiyah Palangkaraya. Palangka Raya.

Tadjoedin, T.H., dan H. Iswanto, 2002. Kiat Mengatasi Permasalahan Praktis: Mengebunkan Mengkudu Secara Intensif. Agro Media Pustaka. Jakarta 